\title{
Apel chrześcijan i ludzi dobrej woli w Polsce o poszanowanie dzieła stworzenia
}

\author{
Appeal of Christians and the People of Good Will in Poland for the Care of Creation
}

Do PANA należy ziemia $i$ wszystko, co ją napetnia, caty świat i jego mieszkańcy.

Ps 24,1

Zebrani 16 maja 2019 r. na konferencji pt. „Kościół wobec kryzysu ekologicznego”, zorganizowanej z okazji 30. rocznicy wydania przez Konferencję Episkopatu Polski listu pasterskiego na temat ochrony środowiska, zabieramy głos w imieniu reprezentowanych przez nas środowisk intelektualistów, przedsiębiorców, organizacji pozarządowych, administracji rządowej i samorządowej, mediów, wspólnot religijnych oraz uczniów i studentów. Świadomi wyzwań, przed którymi staje dziś ludzkość, jesteśmy przekonani o konieczności połączenia wysiłków wszystkich ludzi na rzecz troski o Ziemię - bezpiecznego miejsca życia obecnych i przyszłych pokoleń.

My, chrześcijanie oraz ludzie dobrej woli, świadomi ciążącej na nas odpowiedzialności, zwracamy się do tych, którzy z racji pełnionych funkcji są odpowiedzialni za stan środowiska, oraz do tych, którym leży na sercu pomyślność wszystkich członków ziemskiej wspólnoty życia, o podjęcie konkretnych działań w celu ochrony ziemskiego dziedzictwa. Świadomi różnic, jakie nas dzielą, podejmujemy jednak wspólny apel o zaangażowanie na rzecz troski o otaczający nas świat. Jako chrześcijanie podzielamy wiele motywacji naszych niewierzących sióstr i braci w trosce o przyrodę ze względu na nią samą oraz ze względu na drugiego człowieka. Nasze motywacje sięgają jednak także wiary, która każe nam odpowiedzialnie zarządzać dziedzictwem powierzonym nam przez Stwórcę. Wprawdzie Bóg wyróżnił człowieka spośród wszystkich stworzeń i pozwolił mu „czynić sobie ziemię poddaną” oraz panować „nad rybami morskimi, nad ptactwem powietrznym i nad wszystkimi zwierzętami pełzającymi po ziemi” (Rdz 1,28), to przecież jednocześnie obarczył go odpowiedzialnością za powierzone mu dziedzictwo $(\operatorname{Rdz} 2,15)$. Potwierdził to, zawierając przymierze nie tylko z człowiekiem, lecz także ze wszystkimi innymi istotami żywymi ( $\mathrm{Rdz}$ 9,9-10). Ostatecznie Stwórca nie pozostawił wątpliwości, że Ziemia jest Jego własnością, człowiek jest zaś jedynie jej zarządcą ( $1 \mathrm{Krn}$ 29,11). Jeżeli nie będzie się o nią troszczył, to spotka go za to nieuchronna kara (Ap 11,18). Ponadto Bóg, zapowiadając czasy mesjańskie, zapewnił, że zawrze wówczas kolejne przymierze z całym stworzeniem $\left(\mathrm{Oz}_{2,20}\right)$ i przywróci pierwotną harmonię człowieka z przyrodą (Iz 11,6-9).

My, chrześcijanie, świadomi tego, że sama przyroda oddaje cześć Stwórcy (Ps 148; Dn 3,57-81) i nas zachęca do tego samego 
(Syr 43,11), odczuwamy wielką odpowiedzialność za otaczający nas świat. Jednocześnie jesteśmy świadomi, że często wykraczamy przeciw nakazom Stwórcy, nie okazując przyrodzie należytego szacunku oraz korzystając z niej w sposób egoistyczny i nieodpowiedzialny, co sprawia, że stworzenie wciąż jęczy i wzdycha $(\operatorname{Rz} 8,22)$. W nawiązaniu do tego papież Franciszek mówi, że „zbrodnia przeciw naturze jest zbrodnią przeciw nam samym i grzechem przeciw Bogu" (Laudato $s i$ nr 8). Chrześcijanie są zatem zobowiązani do ekologicznego nawrócenia, które przejawia się w zerwaniu z grzechem wobec przyrody (Laudato si' nr 216-221).

Mamy też świadomość, że prawo ochrony przyrody, by było wystarczająco skuteczne, powinno być wzmacniane działaniami wynikającymi z pobudek religijnych. Jesteśmy przekonani, że działania takie pozytywnie wpłyną na przezwyciężanie kryzysu ekologicznego. Dlatego zwracamy się do naszych sióstr i braci chrześcijan oraz do wszystkich ludzi dobrej woli o podjęcie indywidualnych i wspólnych działań, które będą zmierzały do: ochrony klimatu i oszczędności zasobów naturalnych, niemarnotrawienia żywności i odpowiedzialnej konsumpcji, nieśmiecenia, troszczenia się o zieleń wokół naszych domów, szanowania zwierząt, preferowania transportu publicznego i stosowania innych form redukcji zanieczyszczeń oraz negatywnego wpływu człowieka na środowisko, a także będą zmierzały do troszczenia się o najbardziej potrzebujących, którymi są nie tylko dziś żyjący ludzie i pozostałe istoty żywe, lecz także przyszli mieszkańcy Ziemi. Jednocześnie podzielamy optymizm papieża Franciszka, że z pomocą Stwórcy człowiek zdolny jest do przezwyciężania własnego egoizmu i do budowania bardziej sprawiedliwego świata, który będzie bezpiecznym domem całego stworzenia.

Sygnatariusze niniejszego Apelu zachęcają do podjęcia debaty nad praktycznymi sposobami wprowadzenia w życie zawartego w nim przesłania oraz do upowszechniania jego treści w różnych środowiskach. 